\title{
Pengembangan Variasi Pembelajaran Lompat Jauh Pada Mahasiswa Pendidikan Kepelatihan Olahraga FIK Unimed
}

\author{
Yan Indra Siregar, Rahman Situmeang, Muhammad Faisal Ansari Nasution \\ Fakultas Ilmu Keolahragaan, Universitas Negeri Medan \\ yanindrasiregar@gmail.com, situmeangrahman@gmail.com, faisalnst91@unimed.ac.id
}

\begin{abstract}
Abstrak: Penelitian ini bertujuan untuk mengembangkan pembelajaran atletik nomor lompat jauh di jurusan pendidikan kepelatihan olahraga FIK Unimed melalui beragam variasi pembelajaran. Adapun metode yang digunakan pada penelitian ini adalah penelitian pengembangan. Pada penelitian ini terdapat 8 variasi pembelajaran lompat jauh yang dirancang untuk meningkatkan hasil belajar. Delapan model yang telah disusun terlebih dahulu divalidasi oleh 5 orang ahli dibidang olahraga yaitu 2 orang merupakan pelatih lompat jauh dan 3 orang merupakan akademisi olahraga. Uji kelompok kecil menggunakan 25 orang mahasiswa serta uji coba kelompok besar menggunakan 50 orang mahasiswa. Pada tahap uji coba kelompok kecil, peneliti mengumpulkan data berupa angket yang berisi tentang tanggapan sampel terhadap pemakaian produk penelitian. Dari angket yang dibagikan diperoleh data hasil $89.33 \%$ menginginkan produk ini. Adapun Output yang dihasilkan dari penelitian ini adalah berupa buku yang dapat dijadikan pedoman pembelajaran secara berkesinambungan. Melihat data hasil penelitian besar harapan peneliti bahwa buku ini dapat meningkatkan minat belajar mahasiswa pada bidang atletik khususnya lompat jauh mahasiswa jurusan pendidikan kepelatihan olahraga.
\end{abstract}

Kata Kunci: Variasi pembelajaran, Lompat jauh

\section{Development of Long Jump Learning Variations in the Sports Coaching Education Students of FIK Unimed}

Abstract: This study aims to develop athletic learning for long jump numbers in the sports coaching education department of FIK Unimed through a variety of learning variations. The method used in this research is development research. In this study, there are 8 variations of long jump learning designed to improve learning outcomes. The eight models that have been prepared in advance are validated by 5 sports experts, namely 2 long jump trainers and 3 sports academics. The small group test used 25 students and the large group test used 50 students. At the small group trial stage, researchers collected data in the form of a questionnaire containing sample responses to product research. From the questionnaire, $89.33 \%$ wanted this product. The output produced from this research is a book that can be used as new learning on an ongoing basis. Looking at the research data, the researchers hope that this book can increase students' interest in learning in the field of athletics, especially long jump students majoring in sports coaching education.

Keywords: Variation of learning, Long jump

\section{PENDAHULUAN}

Lompat jauh sebagai salah satu nomor atletik yang diperlombakan membuat para pelatih harus bersaing secara keras dalam membentuk atlet lompat jauh yang baik dan berprestasi. Lompat adalah suatu gerakan mengangkat tubuh dari suatu titik ke titik lain yang lebih jauh atau tinggi dengan ancang-ancang lari cepat atau lambat dengan menumpu satu kaki dan mendaratkan dengan kaki atau anggota tubuh lainnya dengan keseimbangan yang baik (Djumidar, 2007:6-13). Lompat jauh merupakan hasil dari kecepatan horizontal yang dibuat dari ancang-ancang dengan gerak vertikal yang 
dihasilkan dari kaki tumpu, formulasi dari kedua aspek tadi menghasilkan suatu gaya gerak parabola dari titik pusat gravitasi (Djumidar, 2007:12.40).

Didalam menghadapi kemajuan zaman, program latihan menjadi senjata bagi para pelatih dalam menyiapkan atletnya dalam bertarung dilapangan. Pada nomor lompat jauh menjadi tugas pelatih bagaimana mampu menyampaikan tujuan umum latihan lompat jauh ke atlet, (Jarver, 2013: 24) antara lain: 1) memproyeksikan pusat gravitasi (gaya berat) tubuh si pelompat diudara pada kecepatan bergerak ke muka yang maksimum, 2) jauhnya lompatan yang dapat dicapai tergantung pada kecepatan lari, kekuatan, dan percepatan pada saat take off (memindahkan kecepatan horizontal ke gerakan bersudut). Tujuan tersebut dapat dicapai dari pelaksanaan latihan. Secara teori latihan adalah aktivitas atau kegiatan yang terdiri dari berbagai bentuk sikap dan gerak, terarah, berulang-ulang dengan beban yang kian bertambah guna memperbaiki efisiensi kemampuan (Sidik, 2019:5). Seiring dengan defenisi latihan ada juga tujuan latihan yaitu untuk membatu atlet untuk mencapai puncak prestasi dengan peningkatan yang bagus pada tiap latihannya. Harsono (2015:39) menyatakan bahwa "tujuan serta sasaran utama dari latihan adalah membantu atlet untuk meningkatkan keterampilan prestasi semaksimal mungkin. Maka akan selalu ada perubahan, perbaikan dan penyempurnaan agar apa yang diberikan di klub atletik terhadap atletnya dapat digunakan untuk menghadapi tantangan hidup di masa sekarang maupun yang akan datang, klub tersebut bukan hanya tempat untuk berlatih tetapi juga sebagai tempat untuk menyalurkan bakat, agar atlet dapat berprestasi lebih baik kedepannya.

Simaremare (2007:23) mengemukakan pengertian variasi dapat diartikan perbedaan memvariasikan berarti mengubah-ubah bentuk supaya lain dari yang ada atau biasa. Misalnya "Seorang ibu memvariasikan menu makanan yang di hidangkan untuk keluarga setiap hari" bayangkan kita akan merasa bosan jika setiap hari makan-makanan yang sama. Di kehidupan sehari-hari jika kita melihat merasakan mengalami hal atau perisiwa yang sama atau berulang-ulang terus dan kita akan menghilangkan kebosanan itu, kita berusaha membuat perubahan-perubahan dalam menata hidup kita sendiri. Melalui pengembangan variasi latihan lompat jauh diharapkan dapat menambah antusias atlet dalam mengikuti proses latihan yang menyenangkan dan tidak merasakan bosan klub atletik khususnya dalam lompat jauh ini bertujuan untuk membina karakter atlet, serta menjadikan atlet yang aktif dalam bidangnya dan menuju prestasi yang gemilang dimasa depannya.

Variasi mengajar adalah suatu kegiatan guru dalam konteks proses dalam interaksi dalam belajar mengajar yang ditunjukkan untuk mengatasi kebosanan siswa sehingga, dalam situasi belajar mengajar siswa senantiasa menunjukan ketekunan, antusiasme, serta penuh partisipasi. Pembelajaran coaching clinic di juruan Pendidikan Kepelatihan Olahraga tahun 2019 lalu ada 19 orang mahasiswa yang menekuni cabang olahraga atletik. Mereka ditugaskan untuk magang di tempat-tempat latihan atletik yang ada di kota Medan. Untuk membekali mereka dalam manjalani magang dan menambah wawasan kepelatihan mahasiswa calon alumni yang menggeluti cabang olahraga atletik. Melihat dari proses pembelajaran yang sudah dilalui, peneliti sebagai dosen pengampu matakuliah atletik memberikan pembelajaran mengembangkan beberapa variasi latihan dinomor lompat jauh. Hal ini dilakukan untuk menghadirkan proses pembelajaran yang bervariasi sehingga dapat meningkatkan hasil pembelajaran atletik khususnya pada nomor lompat jauh. Meningkatnya hasil belajar diharapkan akan berdampak positif terhadap kualitas alumni PKO dalam bidang Ilmu Kepelatihan dan Pembelajaran pada nomor lompat jauh.

Sugiyono (2014:297) menyatakan bahwa penelitian dan pengembangan adalah penelitian yang digunakan untuk menghasilkan suatu produk tertentu dan menguji keefektifan produk tersebut. Penelitian pengembangan perlu dilakukan untuk mencari atau menciptakan sebuah hal yang baru yang bermanfaat bagi masyarakat luas. Pengembangan adalah proses, cara atau perbuatan mengembangkan sesuatu secara bertahap dan teratur yang menjurus terhadap sasaran yang dikehendaki.

\section{METODE}

Penelitian ini dilaksanakan di Jurusan Pendidikan Kepelatihan Olahraga FIK Unimed pada tahun 2020. Adapun tujuan penelitian ini adalah menghasilkan produk berupa buku panduan yang mendukung dan mempermudah proses pembelajaran yang diharapkan berdampak pada peningkatan hasil belajar bidang atletik khususnya lompat jauh mahasiswa jurusan pendidikan kepelatihan 
olahraga. Metode yang digunakan pada penelitian ini adalah pengembangan yang mencakup mengembangkan produk, menguji keefektifan produk untuk mencapai tujuan yang diinginkan. Subjek penelitian ini mahasiswa jurusan Pendidikan Kepelatihan Olahraga FIK Unimed yang mengambil bidang atletik. Adapun langkah - langkah dari desain penelitian pengembangan adalah sebagai berikut: (1) Pertama yang akan ditentukan adalah potensi dan masalah yang akan dikembangkan, (2) Mengumpulkan informasi/data sebagai landasan pemikiran untuk membuat konsep, (3) Menentukan desain produk (rancangan produk) bentuk rancangan tersebut adalah pengembangan bentuk variasi latihan untuk atlet lompat jauh 2019, (4) Validasi desain, revisi yang dilakukan oleh ahli yang bersangkutan, (5) Perbaikan Desain, setelah direvisi oleh ahli maka peneliti memperbaiki desain produk yang akan dihasilkan, (6) Uji coba produk, uji coba tahap awal ini dilakukan untuk dapat mengumpulkan data sebagai dasar untuk menetapkan kelayakan produk, (7) Revisi produk, dilakukan untuk memperoleh hasil yang sempurna. (8) Uji coba pemakaian. Pemakaian produk yang lebih luas dan penyempurnaan produk. (9) Revisi Produk. Apabila dalam pemakaian produk dalam ujicoba yang lebih luas terdapat kelemahan revisi ini dilakukan sehingga produk lebih sempurna. (10) Pembuatan produk massal. Ini dilakukan apabila produk yang telah diujicoba dinyatakan efektif dan layak untuk diproduksi massal.

Teknik analisis data yang dilakukan antara lain setiap variabel instrumen validasi dihitung jumlah persennya lalu dirata - ratakan dengan variabel yang lain. Setiap validator akan memiliki nilai yang berbeda. Ketiga nilai validator yang terdiri dari beberapa variabel terhadap satu model dirataratakan dan itulah yang menjadi acuan apakah model tersebut digunakan atau tidak. Rumus untuk mengolah tanggapan atau evaluasi dari pelatih atletik lompat jauh dihitung menggunakan rumus persentase yaitu :

$$
\text { Rumus : } \boldsymbol{P}=\frac{\text { JumlahNilaiDiperoleh }}{\text { JumlahTotal }} \boldsymbol{x} 100 \%
$$

Tabel 1. Analisis Persentase Hasil Validasi Terhadap Bentuk Latihan

\begin{tabular}{c|l|l}
\hline PERSENTASE & \multicolumn{1}{|c}{ KETERANGAN } & \multicolumn{1}{c}{ MAKNA } \\
\hline $80 \%-100 \%$ & Valid & Digunakan \\
\hline $60 \%-79 \%$ & Cukup Valid & Digunakan \\
\hline $50 \%-59 \%$ & Kurang Valid & Diganti \\
\hline$<50 \%$ & Tidak Valid & Diganti \\
\hline
\end{tabular}

\section{HASIL DAN PEMBAHASAN}

Penelitian ini menghasilkan 8 variasi latihan yang telah dikembangkan sebagai upaya untuk peningkatan hasil belajar lompat jauh pada pembelajaran atletik khususnya nomor lompat jauh di Pendidikan Kepelatihan Olahraga. Adapun hasil yang didapatkan dari pelaksanaan ujicoba produk adalah sebagai berikut: 1) Dari 25 sampel penelitian, 23 orang $(92 \%)$ menyatakan setuju dengan adanya variasi baru dalam pembelajaran lompat jauh, sedangkan 2 orang $(8 \%)$ menyatakan bahwa tidak setuju karena keberhasilan pembelajaran tergantung pada kemauan peserta pembelajaran sehingga variasi pembelajaran tidak memberikan kontribusi besar bagi keberhasilan pembelajaran, 2) Setelah melihat perlakuan pada ujicoba kelompok kecil, Tim Validator melakukan peninjauan untuk mempertimbangkan kelayakan produk. Setelah melakukan analisis dari 8 variasi tersebut validator menyarankan agar dilakukan pelaksanaan ujicoba tahap berikutnya dengan jumlah sampel yang lebih besar lagi yaitu 50 orang, 3) Setelah melaksanakan ujicoba kelompok besar dengan jumlah sampel 50 orang, 44 orang (88\%) menyatakan setuju dengan variasi yang dihasilkan dan membantu pemahaman serta memudahkan mereka dalam menguasai pelaksanaan lompat jauh dengan baik. Sedangkan 6 
orang $(12 \%)$ menyatakan tidak setuju karena tidak ingin mendalami cabang olahraga atletik, 4) Setelah melakukan kedua tahap ujicoba maka didapatkan hasil sebesar $89.33 \%$ sampel menginginkan adanya variasi baru sehingga produk ini layak untuk dipublikasikan.

\section{Uji Coba Kelompok Kecil}

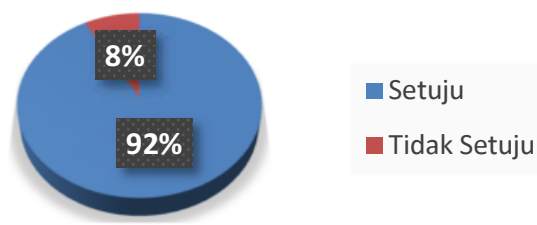

Gambar 1. Persentase Hasil Uji Coba Kelompok Kecil

\section{Uji Coba Kelompok Besar}

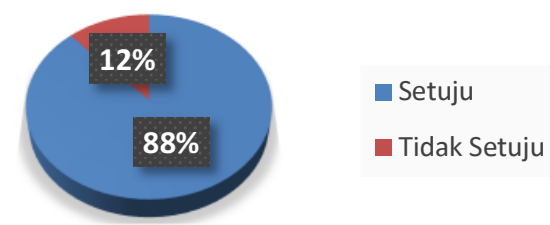

Gambar 2. Persentase Hasil Uji Coba Kelompok Besar

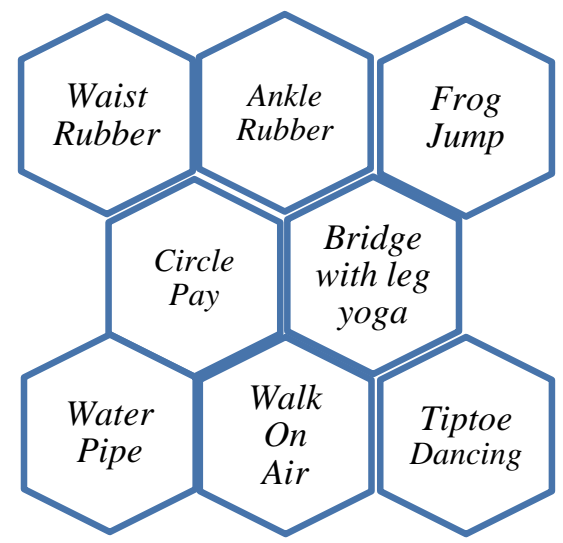

Gambar 3. Delapan Variasi Latihan Lompat Jauh

\section{SIMPULAN}

Berdasarkan hasil penelitian dapat diambil kesimpulan bahwa penelitian menghasilkan produk berupa buku yang berisi delapan variasi pembelajaran lompat jauh yang telah diujicobakan kepada 75 orang terdiri dari 25 orang saat kelompok kecil dan 50 orang saat uji kelompok besar. Adapun hasil angket yang diberikan kepada subjek penelitian saat ujicoba kelompok kecil yakni 23 orang (92\%) 
menyatakan setuju dengan adanya variasi baru dalam pembelajaran lompat jauh, sedangkan 2 orang (8\%) menyatakan bahwa keberhasilan pembelajaran tergantung pada kemauan peserta pembelajaran sehingga variasi pembelajaran tidak memberikan kontribusi besar bagi keberhasilan pembelajaran. Sementara itu hasil angket saat uji coba kelompok besar diperoleh 44 orang (88\%) menyatakan setuju dengan variasi yang dihasilkan dan membantu pemahaman serta memudahkan mereka dalam menguasai pelaksanaan lompat jauh dengan baik sedangkan 6 orang $(12 \%)$ menyatakan tidak setuju karena tidak ingin mendalami cabang olahraga atletik. Dari kedua uji coba yang dilakukan diperoleh data sebesar $89.33 \%$ menginginkan produk ini.

\section{DAFTAR PUSTAKA}

Djumidar A, Moechamad. (2004). Dasar-Dasar Atletik. Jakarta: Universitas Terbuka

Harsono. (2015). Kepelatihan Olahraga. Bandung: PT. Remaja Rosdakarya

Jarver, Jess. (2013). Belajar dan Berlatih Atletik, Bandung: Pionir Jaya

Sidik, Dikdik Zafar. 2019. Pelatihan Kondisi Fisik. Bandung: PT. Remaja Rosdakarya

Simaremare, Aman. (2007). Kemampuan Dasar Mengajar, Medan: Universitas Negeri Medan

Sugiyono. 2014. Metode Penelitian Kuantitatif, Kualitatif dan $R \& D$. Bandung: Alfabeta 